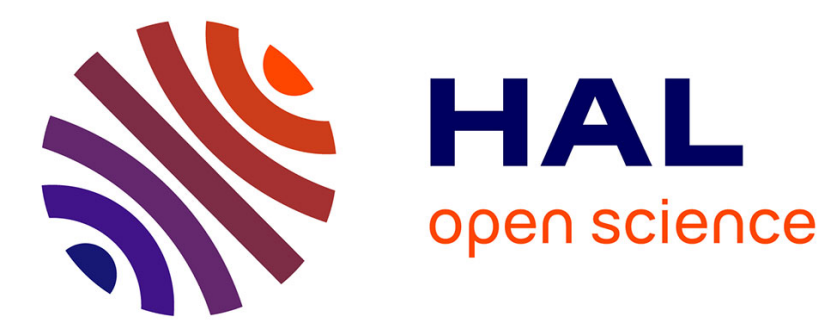

\title{
Single cell transcriptomics reveal trans-differentiation of pancreatic beta cells following inactivation of the TFIID subunit Taf4
}

Thomas Kleiber, Guillaume Davidson, Gabrielle Mengus, Igor Martianov, Irwin Davidson

\section{To cite this version:}

Thomas Kleiber, Guillaume Davidson, Gabrielle Mengus, Igor Martianov, Irwin Davidson. Single cell transcriptomics reveal trans-differentiation of pancreatic beta cells following inactivation of the TFIID subunit Taf4. Cell Death and Disease, 2021, 12 (8), pp.790. 10.1038/s41419-021-04067-y . hal-03391503

\section{HAL Id: hal-03391503 \\ https://hal.science/hal-03391503}

Submitted on 3 Nov 2021

HAL is a multi-disciplinary open access archive for the deposit and dissemination of scientific research documents, whether they are published or not. The documents may come from teaching and research institutions in France or abroad, or from public or private research centers.
L'archive ouverte pluridisciplinaire HAL, est destinée au dépôt et à la diffusion de documents scientifiques de niveau recherche, publiés ou non, émanant des établissements d'enseignement et de recherche français ou étrangers, des laboratoires publics ou privés. 

pancreatic beta cells following inactivation of the TFIID subunit Taf4

Thomas Kleiber ${ }^{1,2,3,4,5,7}$, Guillaume Davidson (iD ${ }^{1,2,3,4,7}$, Gabrielle Mengus ${ }^{1,2,3,4}$, Igor Martianov ${ }^{1,2,3,4}$ and Irwin Davidson (iD) $1,2,3,4,6 \bowtie$

(c) The Author(s) 2021

Regulation of gene expression involves a complex and dynamic dialogue between transcription factors, chromatin remodelling and modification complexes and the basal transcription machinery. To address the function of the Taf 4 subunit of general transcription factor TFIID in the regulation of insulin signalling, it was inactivated in adult murine pancreatic beta cells. Taf4 inactivation impacted the expression of critical genes involved in beta-cell function leading to increased glycaemia, lowered plasma insulin levels and defective glucose-stimulated insulin secretion. One week after Taf4-loss, single-cell RNA-seq revealed cells with mixed beta cell, alpha and/or delta cell identities as well as a beta cell population trans-differentiating into alpha-like cells. Computational analysis of single-cell RNA-seq defines how known critical beta cell and alpha cell determinants may act in combination with additional transcription factors and the NuRF chromatin remodelling complex to promote beta cell trans-differentiation.

Cell Death and Disease (2021)12:790; https://doi.org/10.1038/s41419-021-04067-y

\section{INTRODUCTION}

Pancreatic Langerhans islets comprise multiple hormone-secreting cell types that cooperate to regulate glucose homeostasis in the organism. Plasticity and trans-differentiation between endocrine cell populations have been described in diabetes, genetically modified mice and after various pathological or chemical treatments [1-6]. Alpha cells have a plastic epigenetic state with many loci showing bivalent chromatin modifications [7] and can be converted to beta-like insulin-secreting cells by overexpression of beta cell-determining factors [8] or loss of Arx and Dnmt1 [9]. In type 2 diabetes, hyperglycaemia may induce beta-cell dedifferentiation through reversion to a Ngn3-expressing precursor state $[1,10-13]$. However, with some exceptions [9, 14, 15], the transcriptional mechanisms underlying changes in cell identity are not fully understood.

Regulation of gene expression requires a dynamic dialogue between transcription factors binding cis-regulatory elements, chromatin remodelling and modification complexes and the basal transcription machinery [16-20]. Basal transcription factor TFIID comprising the TATA-box binding protein (TBP) and 13-14 TBP-associated factors (TAFs) plays a critical role in this communication and in pre-initiation complex (PIC) formation $[21,22]$. TFIID is organised in three lobes A-C [22-24]. The histone-like TAF4-TAF12 heterodimer is crucial for the structural integrity of lobes $A$ and $B[25,26]$. In lobe $B$, the conserved TAF4 C-terminal domain contacts promoter DNA and the TFIIATBP module suggesting they promote TBP DNA binding and fix the distance between the TBP binding and the transcription start sites.

Genetic Taf4 inactivation in mouse leads to specific effects on gene expression that may in part be explained by redundancy with its paralog TAF4B that maintains TFIID integrity in absence of TAF4 $[27,28]$. We used somatic inactivation to address Taf4 function in the embryonic and adult epidermis or neonatal hepatocytes [26, 27, 29-31] and germline inactivation to address its role during embryogenesis [28]. In each biological context, Taf4 regulated specific gene expression programs and functions, in particular in advanced stages of embryonic tissue differentiation.

We used Insulin-Cre-ER ${ }^{\mathrm{T2}}$ transgenics to inactivate Taf4 in murine adult beta cells showing that it regulates an extensive gene expression program including critical components of the insulin signalling pathway. Taf4 loss also impacts beta cell identity and computational analysis of single-cell transcriptomics data defined how known beta and alpha cell determinants may act in combination with additional transcription factors and the NuRF chromatin remodelling complex to promote beta-cell transdifferentiation into alpha-like glucagon-expressing cells.

\section{MATERIALS AND METHODS}

\section{Genetically engineered mice}

Mice with the floxed Taf4 alleles as previously described [27] were crossed with previously described [32] Ins-Cre-ER ${ }^{\mathrm{T2}}$ transgenics and Taf4 inactivated by subcutaneous injection 1 time per day for 3 days with $5 \mu$ of

\footnotetext{
${ }^{1}$ Institut de Génétique et de Biologie Moléculaire et Cellulaire. BP 163, 67404 Illkirch Cedex, C.U, Strasbourg, France. ${ }^{2}$ Centre National de la Recherche Scientifique, UMR7104 Illkirch, France. ${ }^{3}$ Institut National de la Santé et de la Recherche Médicale, U1258 Illkirch, France. ${ }^{4}$ Université de Strasbourg, Illkirch, France. ${ }^{5}$ Orphazyme, Ole Malloes Vej 3, 2200 Copenhagen, Danmark. ${ }^{6}$ Equipe Labélisée Ligue National contre le Cancer, Alsace, France. ${ }^{7}$ These authors contributed equally: Thomas Kleiber, Guillaume Davidson.

凶email: irwin@igbmc.fr

Edited by A. Finazzi-Agrò
}

Received: 2 March 2021 Revised: 22 July 2021 Accepted: 26 July 2021

Published online: 12 August 2021 
Tamoxifen diluted in oil (final concentration $10 \mathrm{mg} / \mathrm{ml}$ ). Fasting blood glucose and insulin levels were measured over a period of 20 weeks with one measurement per week on the same day at the same time. Glycaemia was measured using a glucometer and insulin levels using the Milliplex Map Kit (Mouse Metabolic Magnetic Bead Panel. MMHMAG-44K, Millipore). To assess glucose tolerance, mice were fasted for 12 hours before the first glucose measure and then injection of $100 \mu$ of glucose solution $(t=0,2 \mathrm{~g}$ of glucose/ $\mathrm{kg}$ mouse weight). Insulin levels were monitored in blood samples taken over a 30 -min period starting $5 \mathrm{~min}$ before the glucose injection. The analysed cohort comprised animals from 6 litters generated by independent sets of Tam injections over a period of more than 1 year. All animals were at the same age at the time of Tam injection. Littermates of these animals were sacrificed for the histology and RNA-seq experiments. In total, more than 7 litters (more than 60 individual mice) from independent crosses were used in this study. Animals with the correct genotypes were randomly chosen from each litter for all types of experiments. No animals were excluded from experimentation unless they were evidently in poor health.

All animal experiments were performed in accordance with European and national guidelines and policies (2010/63/UE directive and French decree 2013-118) and with approval of the National Ethics Committee.

\section{Immunostaining}

Pancreas were dissected and fixed overnight in $4 \%$ paraformaldehyde, washed with PBS, dehydrated, paraffin embedded, and sectioned at $5 \mu \mathrm{m}$. For antigen retrieval, the sections were boiled for $20 \mathrm{~min}$ in $10 \mathrm{mM}$ of sodium citrate buffer. Sections were permeabilized with $3 \times 5 \mathrm{~min} 0.1 \%$ Triton in PBS, blocked for $1 \mathrm{~h}$ in $5 \%$ Neutral Goat Serum (NGS) in PBS, and incubated overnight in 5\% NGS with primary antibodies: mouse antiGlucagon [K79bB10] (Abcam, ab10988), Guinea Pig anti-Insulin (Dako IR00261-2) and mouse anti-TAF4 (TAF II p135) (Santa Cruz (sc-136093). Sections were washed $3 \times 5$ min $0.1 \%$ Triton in PBS, and incubated with secondary antibodies: Goat anti-Guinea pig IgG H\&L Alexa Fluor ${ }^{\circledR} 647$ (Abcam ab150187) and Goat anti-Mouse lgG H\&L Alexa Fluor ${ }^{\circledR} 488$ (Abcam ab150117) for $2 \mathrm{~h}$. Sections were subsequently incubated with $1 / 2000$ Hoechst nuclear stain for $10 \mathrm{~min}$, washed $3 \times 5 \mathrm{~min}$ in PBS, dried, and mounted with Vectashild. For Taf4 and Gcg co-staining the guinea pig antiGcg antibody (LINCO, 4031-01 F) was used after $20 \mathrm{~min}$ of epitope retrieval. For GFP and Gcg co-staining, frozen cryostat sections were used without epitope retrieval. Gcg was detected with mouse anti-Glucagon [K79bB10] (Abcam ab10988) and chicken anti-mouse IgG Alexa Fluor ${ }^{\circledR} 647$ (Thermo Scientific, \# A-21463).

\section{Isolation of intraductal Langerhans islets}

Anesthetized mice $(40 \mu \mathrm{L}$ ketamine $(100 \mathrm{mg} / \mathrm{mL})+24 \mu \mathrm{L}$ xylazine $(20 \mathrm{mg} /$ $\mathrm{mL})+160 \mu \mathrm{L} \mathrm{NaCl}$ intraperitoneal injection per mouse) were injected in the pancreas with $4 \mathrm{ml}$ of collagenase solution $(7 \mathrm{ml} \mathrm{HBSS}, 70 \mu \mathrm{L}$ HEPES $(10 \mu \mathrm{M})$ (Gibco), 16,5 $\mu \mathrm{L}$ DNAse (10 mg/mL) (sigma DN5), $14 \mathrm{mg}$ collagenase $(2 \mathrm{mg} / \mathrm{mL}$ ) (sigma Type V), and for isolation of RNA $2.3 \mu \mathrm{L}$ of RNAsine $(40 \mathrm{U} / \mu \mathrm{L})$. The pancreas was dissected and placed a tube containing $2 \mathrm{ml}$ collagenase solution and incubated at $37 \mathrm{~min}$ at $38^{\circ} \mathrm{C}$ before stopping with $30 \mathrm{~mL}$ Quenching Buffer (QB; $122 \mathrm{~mL}$ HBSS $+2.9 \mathrm{~mL}$ HEPES $(25 \mu \mathrm{M})+0.6 \mathrm{~g}$ BSA $(0.5 \%)$ and 2 cycles of centrifugation at $1200 \mathrm{rpm}$ for $2 \mathrm{~min}$ at $4{ }^{\circ} \mathrm{C}$. The pellet was suspended in $10 \mathrm{ml}$ of Histopaque 1100 (5 ml histopaque 1077; Sigma 10771 and $6 \mathrm{ml}$ histopaque 1119; Sigma 11191), centrifuged for $20 \mathrm{~min}$ at $1500 \mathrm{rpm}$ at $4{ }^{\circ} \mathrm{C}$ and the pellet washed two times with QB. The supernatant was discarded and pelleted islets transferred to a bacterial culture dish to be collected by pipetting. Purified islets were then cultured for $24 \mathrm{~h}$ in RPMI1640 (HEPES $25 \mathrm{mM}$ ) + final $2 \mathrm{mM}$ L-glutamine (Gibco $11875-093)+10 \%$ FCS $95+1 \%$ Penicillin/Streptomycin. Intracellular ATP concentration was measured with the Luminescent ATP Detection Assay Kit (ab113849) on purified islets that were further dissociated to obtain a single-cell population and sorted by flow cytometry to normalize the numbers of cells used on a LSRII Fortessa (BD Biosciences).

\section{Bulk RNA-seq from isolated islets}

RNA was extracted from islets from 2 mice per genotype for each biological replicate with Nucleospin RNA plus XS (Macherey-Nagel). Complementary DNA was generated and linearly amplified from $3 \mathrm{ng}$ total RNA using the Ovation RNA-seq V2 system (NuGEN technologies Inc., Leek, The Netherlands), according to the manufacturer's instructions. The amplified CDNA was then purified using Agencourt AMPure XP beads (Beckman-Coulter, Villepinte, France) in a 1.8:1 bead to sample ratio and fragmented by sonication using a Covaris E220 instrument (with duty cycle: 10\%, maximum incident power: 175 watts and cycles/burst: 200 for $120 \mathrm{~s})$. The RNA-seq libraries were generated from $100 \mathrm{ng}$ fragmented cDNA using the Ovation Ultralow v2 library system (NuGEN technologies Inc., Leek, The Netherlands) according to the manufacturer's instructions, with only 6 PCR cycles for library amplification. The final libraries were verified for quality and quantified using capillary electrophoresis before sequencing on an Illumina Hi-Seq4000. and Reads were preprocessed using cutadapt version 1.10 in order to remove adapter and low-quality sequences (Phred quality score below 20). After this preprocessing, reads shorter than 40 bases were discarded. Reads were mapped to rRNA sequences using bowtie version 2.2.8, and reads mapping to rRNA sequences were removed. Reads were mapped onto the $\mathrm{mm} 9$ assembly of Mus musculus genome using STAR version 2.5.3a. Gene expression quantification was performed from uniquely aligned reads using htseqcount version 0.6.1p1, with annotations from Ensembl version 67 and "union" mode. Only non-ambiguously assigned reads were retained. Read counts were normalized across samples with the median-of-ratios method [33]. Comparisons of interest were performed using the Wald test for differential expression [34] and implemented in the Bioconductor package DESeq2 version 1.16.1. Genes with high Cook's distance were filtered out and independent filtering based on the mean of normalized counts was performed. $P$-values were adjusted for multiple testing using the Benjamini and Hochberg method [3]. Heatmaps were generated with R-package pheatmap v1.0.12. Deregulated genes were defined as genes with log2 (fold change) $>1$ or $<-1$ and adjusted $p$-value $<0.05$. Gene ontology analyses were performed using GSEA (https://www.gsea-msigdb.org/gsea/ index.jsp) or David (https://david-d.ncifcrf.gov/).

\section{ATAC-seq from isolated islets}

ATAC-seq was performed from 20,000 cells from isolated islets. Sequenced reads were mapped to the mouse genome assembly $\mathrm{mm} 9$ using Bowtie [35] with the following arguments: "-m 1 --strata --best -y -S -I 40 -p 2".

After sequencing, peak detection was performed using the Malpha cellS software [36] v2.1.1.20160309. Peaks were annotated with Homer(http:// homer.salk.edu/homer/ngs/annotation.html) using the GTF from ENSEMBL v67. Peak intersections were computed using Bedtools [37] Global Clustering was done using segMINER [38]. In silico footprinting signatures were calculated using TOBIAS [39] (v0.5.1; https://github.com/loosolab/ TOBIAS/), differential footprinting scores were plotted with R-package ggplot2 (https://ggplot2.tidyverse.org.).

\section{Single-cell RNA-seq from dissociated islets}

After islet dissociation, further dissociation was performed with Accutase (A6964, Sigma) at $27^{\circ} \mathrm{C}$ for $5 \mathrm{~min}$ and the cells were suspended in culture medium. Cells were then sorted by flow cytometry to select only live cells. Three hundred islets from a male WT mouse and 300 islets pooled from two male mutant mice 1 week or 5 weeks after Taf 4 inactivation were used for scRNA-seq. Cell capture was performed using 10X Genomics Chromium Analyzer. After sequencing, raw reads were processed using CellRanger ( $\mathrm{v}$ 3.1 ) to align on the mm10 mouse genome, remove unexpressed genes and quantify barcodes and UMIs. Data were then analysed in R (v3.6.3). For the WT sample only, potential doublets were removed by manually filtering out cells expressing high levels of Ins $1+\mathrm{Gcg}$, Ins $1+$ Sst or Gcg + Sst and then by running R-package DoubletFinder [40]. The WT sample was downscaled to 12,000 cells before aggregation with Taf $4^{\text {b- }}{ }^{-1} 5$-week sample and analysed using Seurat v3.1.4 [41] following the guided clustering tutorial vignette. Samples were first aggregated with the "CellRanger aggr" and then normalized and scaled together in Seurat. Only cells with feature count ranging from 200 to 1500 and with percentage of mitochondrial reads $<15 \%$ were kept for the analysis. Counts are normalized with the "LogNormalize" method and data are scaled to remove unwanted sources of variation. Clustering was done on most variable features using 12 PCs and a resolution of 0.8 . Regulome analyses were performed using the SCENIC v1.1.2.2 package.

\section{RESULTS}

\section{Inactivation of Taf4 in adult pancreatic beta cells}

To inactivate Taf4 selectively in adult pancreatic beta cells, mice with floxed Taf4 alleles $[26,27]$ were crossed with an Ins $1:: \mathrm{Cre}^{-E^{T 2}}$ transgenic driver [32] to generate Ins $1:: \mathrm{Cre}^{-\mathrm{ER}^{\mathrm{T} 2}:: \mathrm{Taf}_{4}{ }^{\text {lox/lox }} \text { or Taf4 }}{ }^{+/+}$ animals. At 11-13 weeks of age, animals of each genotype were 
A

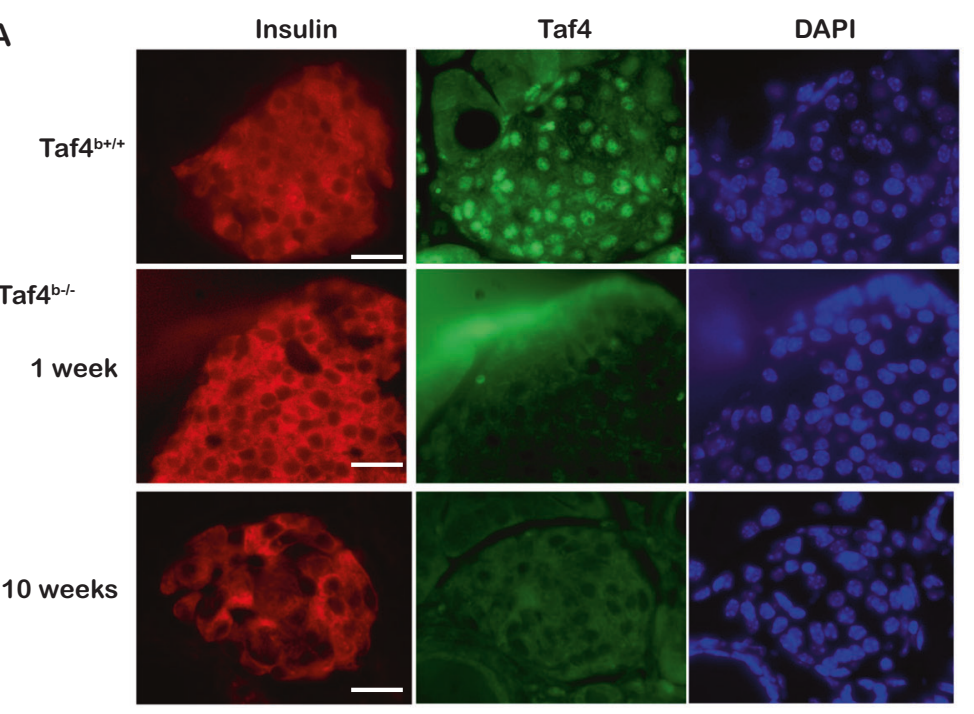

B



Fig. 1 Inactivation of Taf4 in beta cells. A Immunostaining of Langerhans islets from mice with the indicated genotypes for Taf4 or insulin as indicated. The number of weeks after Tam injection are indicated. B Immunostaining of Langerhans islets as above but with the addition of the Taf4-DAPI merge. Representative Taf4-positive nuclei at 34 and 55 weeks are indicated by arrows, not to be confounded with the stronger non-specific staining indicated by ${ }^{*}$. Scale bar $=100 \mu \mathrm{M}$.

injected with Tamoxifen (Tam) on 3 consecutive days to generate Taf $^{\text {b- }-}$ mice lacking Taf4 in beta cells and control Taf4 ${ }^{+/+}$animals maintaining Taf4 expression. Islet immunostaining revealed Taf4 loss 1 week after injection in Taf $4^{\mathrm{b}-{ }_{-}}$animals, whereas it was clearly visible in Tam injected Ins $1:: \mathrm{Cre}^{-E^{\mathrm{T} 2}}{ }^{:: T_{a f}{ }^{+/+}}$controls (Fig. 1A). No Taf4 was detected in Taf $^{\mathrm{b}-{ }^{--}}$animals 3 and 10 weeks after Tam injection, but it reappeared in a sub-population of beta cells after 34 weeks (Fig. 1A and B and Supplementary Fig. 1A). After 55 weeks, islets comprised Taf4-expressing and non-expressing beta cells with insulin staining being more intense in Taf4-expressing beta cells.
Loss of Taf4 in all islet cells was inconsistent with the use of the Ins $1::$ Cre-ER $^{\text {T2 }}$ transgenic driver as its expression should persist in alpha cells. As antigen retrieval treatment necessary for Taf4 staining may result in loss of peripheral alpha cells, we used frozen islet sections. Upon Taf4 and Gcg co-staining, nuclear Taf4 was seen in $\mathrm{Taf}^{+/+}$beta cells and co-staining with Gcg in peripheral alpha cells (Supplementary Fig. 1B). Taf4 expression persisted in Taf4 ${ }^{\mathrm{b}-1-}$ Gcg-expressing cells, but was lost from the beta cells showing selective Taf4 inactivation in beta cells. 
A

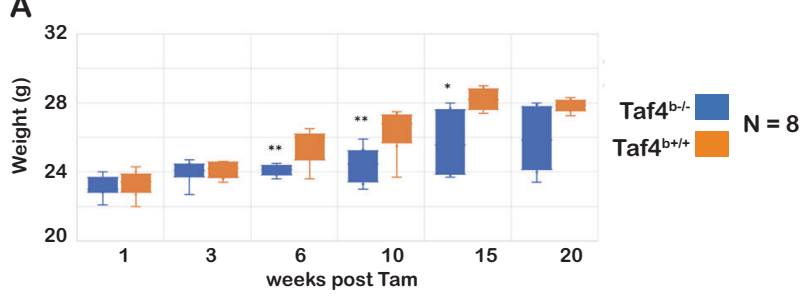

B

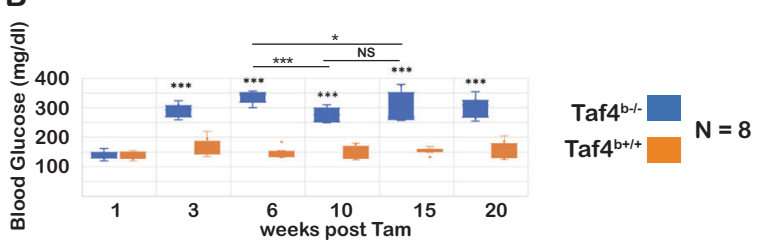

C

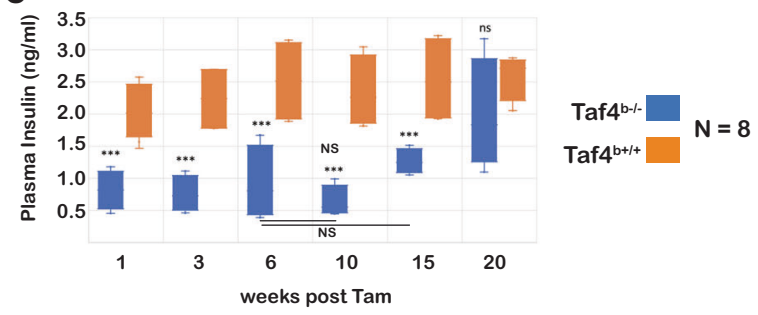

D

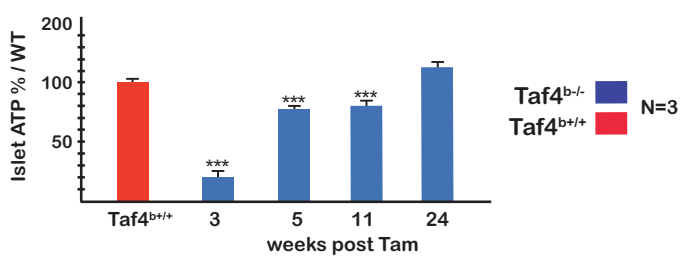

E
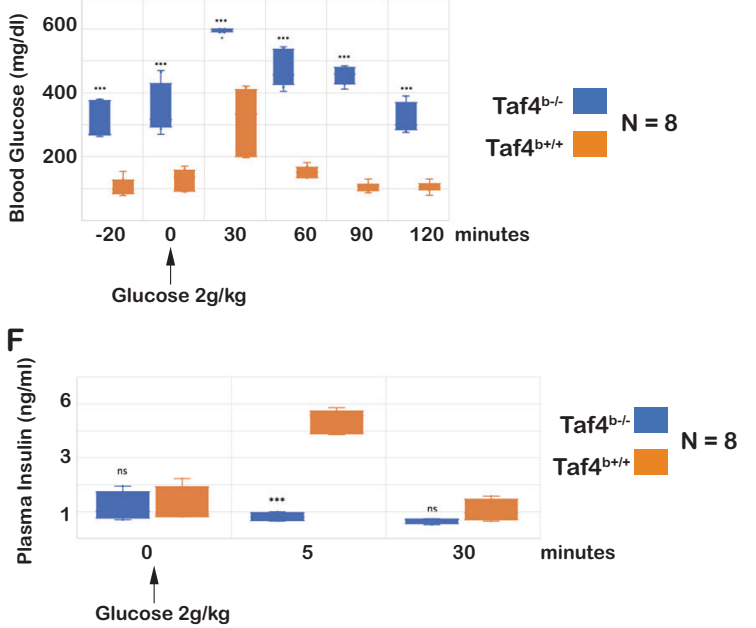

Defective glucose-stimulated insulin secretion upon Taf4 inactivation

We examined different physiological parameters over 20 weeks following Taf4 inactivation. Compared to Taf $4^{+/+}$littermates, Taf $4^{\mathrm{b}-/-}$ animals showed progressive reduction in body weight (Fig. 2A). Fasting blood glucose levels in otherwise ad libitum-fed mice indicated a potent increase in glycaemia after 3 weeks (Fig. 2B) that persisted over 20 weeks, although levels were mildly but significantly reduced after 10 weeks. Plasma insulin levels were also reduced between weeks 1-10, but recovered to those of $\mathrm{Taf}^{+/+}$animals at
Fig. 2 Physiological parameters of Taf ${ }^{b-/-}$ animals. A Weight of Taf $^{b+1+}$ and Taf4 ${ }^{b-1-}$ animals at the indicated number of weeks following Tam injection. B, C Blood glucose and insulin levels of $\mathrm{Taf}^{b+1+}$ and Taf4 ${ }^{b-1-}$ animals at the indicated number of weeks following Tam injection. The * above the bars indicate the significant difference between $\mathrm{Taf}_{4}{ }^{b+/+}$ and $\mathrm{Taf}_{4}{ }^{b-/-}$ animals at each time point, whereas ${ }^{*}$ and NS above/below the lines indicate significant or non-significant differences between the $\operatorname{Taf}^{b-1-}$ values at the indicated times. D ATP content of isolated islets from control animals or from Taf4 ${ }^{b-1-}$ animals at the indicated number of weeks following Tam injection. Values are expressed as a \% of the Taf $4^{b+/+}$ values at each time point taken as $100 \%$. E Blood glucose levels at the indicated times following injection of glucose in control and Taf $^{b-1-}$ animals. Mice at 14 weeks were injected with Tam and glucose administered 3 weeks following Tam treatment. F Plasma insulin levels from the same protocol. $T$-test with two-tailed $P$-value analyses and confidence interval $95 \%$ were performed by Prism 5 . $P$-values: ${ }^{*} p<0.05 ;{ }^{* *} p<0.01 ;{ }^{* *} p<0.001$. Data are mean \pm SD from $N=8$ or $N=3$ as indicated.

later times (Fig. 2C). Islet ATP levels strongly decreased after 3 weeks in the Taf $4^{\mathrm{b}-1-}$ animals, followed by progressive recovery between 11 and 24 weeks (Fig. 2D). Loss of Taf4 therefore resulted in increased glycaemia and lowered plasma insulin that were partially restored after 10 weeks. As a result, Taf $^{\text {b- }}{ }^{-1}$ animals did not show total loss of beta-cell function and no premature death was seen with only rare Taf4-expressing or mutant mice dying over 14 months of surveillance.

Taf4 loss further led to defective glucose-stimulated insulin secretion (GSIS). Fasting Taf4 ${ }^{\mathrm{b}-1-}$ animals and their $\mathrm{Taf}^{+/+}$ littermates 3 weeks after Tam injection were injected with glucose and the resulting plasma glycaemia and insulin levels were monitored. Before injection, the Taf4 ${ }^{\mathrm{b}-1-}$ animals showed elevated glycaemia that was further increased $30 \mathrm{~min}$ after glucose administration (Fig. 2E) and persisted over $90 \mathrm{~min}$ returning to basal values by $120 \mathrm{~min}$. In contrast, their $\mathrm{Taf}^{+/+}$ littermates showed a lower increase in glycaemia that returned to basal values after $90 \mathrm{~min}$. Analogous results were seen using animals 2 and 4 weeks after Tam injection (data not shown). Similarly, glucose administration in Taf4 ${ }^{\mathrm{b}-1-}$ animals failed to increase plasma insulin levels as seen in $\mathrm{Taf4}^{+/+}$animals (Fig. 2F).

Taf4 regulated gene expression programs in beta cells We performed RNA-seq from $\mathrm{Taf}_{4}^{+/+}$islets and from Taf4 ${ }^{\mathrm{b}-1-}$ islets 1, 3 and 5 weeks after Tam injection (Fig. 3A, B and Supplementary Dataset 1). At 1 week, around 1000 genes were up-or down-regulated (Fig. 3A and Supplementary 2A, B). At 3 and 5 weeks, the number of de-regulated genes strongly increased (Fig. 3A and Supplementary 2A, B). More than 300 genes were downregulated under all conditions. At 1 week, genes critical for beta-cell function such as S/c2a2, Trpm5, Ins1 or involved in calcium signalling and cell contact were downregulated (Supplementary Fig. 2C). Upregulated genes were strongly enriched in inflammatory/stress response including numerous chemokines and Reg3a, Reg3b and Reg3g (Supplementary Fig. 2C) as well as in oxidative phosphorylation, DNA metabolism and general transcription factors (Fig. 3A and Supplementary Dataset 1). Expression of the alpha and delta cell markers Gcg and Sst was also rapidly upregulated and then attenuated with time (Supplementary Fig. 2C).

While an increasing number of genes was deregulated over time, we identified sets of genes whose normal expression was partially restored. Expression of a subset of genes strongly downregulated after 1 week was progressively restored after 3 and 5 weeks (Fig. 3A and Supplementary 2D). Similar results were seen with upregulated genes the most striking example being the inflammatory/stress response genes upregulated after 1 week but restored to almost normal after 3 and 5 weeks. 
A



Down-regulated

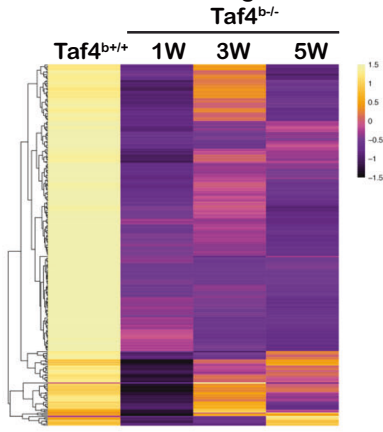

WT W1 W3 W5

B
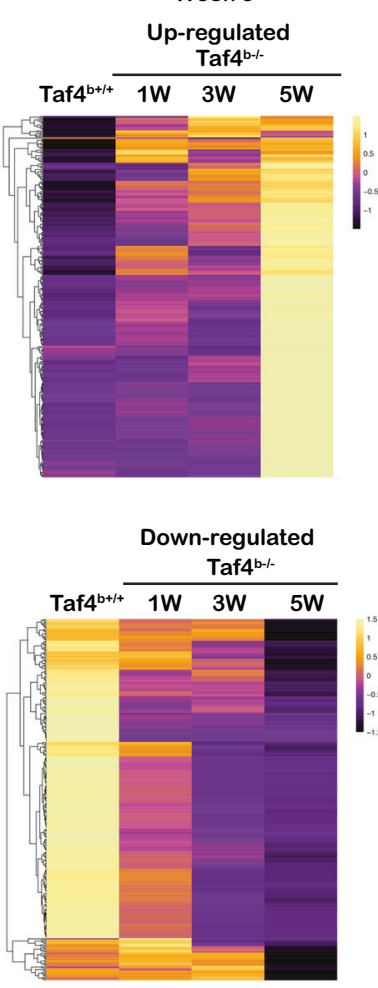
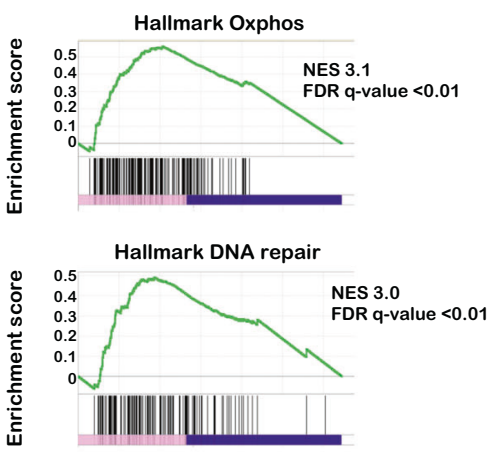

Week 1
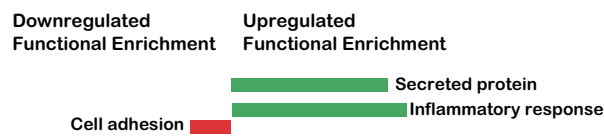

Glycoprotein

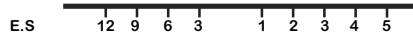

Downregulated Upregulated

KEGG KEGG

Calcium signaling Oxidative phosphorylation

Cytokine/Cytokine receptor

ECM rokine/Cytokinereceptor

Enrichment $\begin{array}{llllllllll}1 & 1 & 1 & 1 & 1 & 1 & 1 & 1\end{array}$
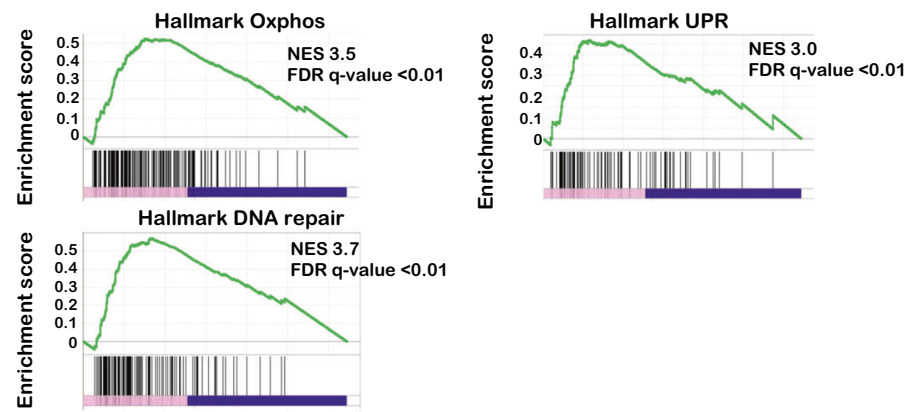

Week 5

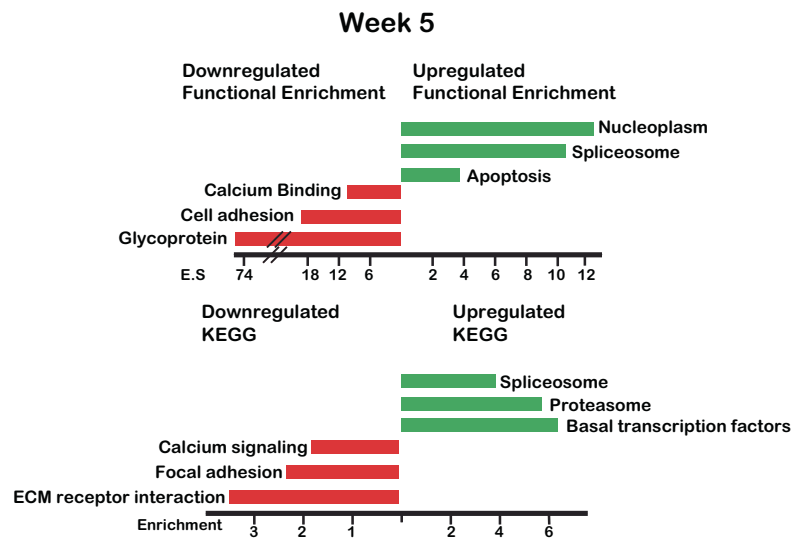

Fig. 3 Effects of Taf4 inactivation on islet gene expression. A Heatmap showing the expression of the 100 genes most up and downregulated 1 week after Taf4 inactivation. Right hand panels show the GSEA and ontology analyses of the de-regulated genes. B Heatmap showing the expression of the 100 genes most up and downregulated 5 weeks after Taf 4 inactivation. Right hand panels show the GSEA and ontology analyses of the de-regulated genes. 
Upregulation of genes involved in chromatin organisation, RNA metabolic functions and transcription were observed after 3 weeks and persisted at 5 weeks (Fig. 3B and Supplementary 2D), suggesting that the acute stress response was followed by chromatin reorganisation and compensation for loss of Taf4 by upregulation of Taf $4 b$ and Taf12. Indeed, Taf $4 b$ expression was much lower than that of Taf4 in wild-type islets.

ATAC-seq on isolated islets revealed a global increase in accessibility after 1 week, but at the proximal promoter, the number of accessible sites was rather enriched in $\mathrm{Taf}^{+/+}$. (Supplementary Fig. 3A). A similar result was seen after 5 weeks (Supplementary Fig. 3B). To identify transcription factors showing differential occupancy, we carried out in silico footprinting analyses at the proximal promoter [39]. Binding of Hox-domain containing transcription factors including critical beta-cell factors Nkx6-1 and Hnf1b was enriched in $\mathrm{Taf4}^{+/+}$, whereas Yy2, Arnt2, Bhlhe41 and Mycn were enriched in $\mathrm{Taf4}^{-1-}$ (Supplementary Fig. 3C). Similarly, after 5 weeks, enriched binding of several factors including Yy2, Nrf1 was observed (Supplementary Fig. 3D).

ATAC-seq and RNA-seq data indicated that Taf4 loss led to reduced chromatin accessibility at proximal promoters with reduced binding of critical beta-cell factors together with expression of genes essential for beta-cell function, but enhanced binding of a new set of transcription factors.

\section{Taf4 inactivation results in loss of beta-cell identity and trans- differentiation into alpha-like cells}

While the above data provided an overall view of gene expression changes in islets, they did not assess whether Taf4 loss affected only beta-cell gene expression or if it impacted gene expression in other cell types as suggested by increased Gcg and Sst expression. To address this, we performed single-cell (sc)RNA-seq from purified dissociated Langerhans islets from $\operatorname{Taf4}^{+/+}$and Taf4 ${ }^{b-/-}$ mice 1 and 5 weeks after Tam injection.

Analyses of around 12,000 cells from $\mathrm{Taf}^{+/+}$islets identified the major endocrine populations with 4 beta cell clusters expressing high Ins1 and Ins2 (clusters $0-2$ and 4 in Fig. 4A). Cluster 3 represented Gcg-expressing alpha cells, cluster 6 Sstexpressing delta cells and cluster 5 an acinar population (Fig. 4A). The 4 beta-cell sub-populations were distinguished by a strong ER stress signature in cluster 2 , while cluster 0 represented potential secretory cells with high S/c2a2, Abcc8 and G6pc2 and lower Ins 1/2 that was higher in clusters 1 and 4 (Supplementary Fig. 4).

We analysed 10,666 cells 5 weeks after Taf4 inactivation distinguishing 4 beta cell populations with high Ins2 (clusters 2-4 and 6, Fig. 4B), but reduced Ins1 as noted in the bulk RNA-seq. Cluster 1 corresponded to Sst-expressing delta cells, while clusters 0 and 5 corresponded to Gcg-expressing alpha cells. Aggregation of Taf $^{+/+}$and week 5 data sets (Fig. 4C, D and Supplementary Fig. 5) clearly distinguished $\mathrm{Taf}^{+/+}$beta cell populations from $\mathrm{Taf}^{-l}$ based on high Ins1 expression in Taf4 ${ }^{+/+}$(clusters 0, 5, 6 and 9) from Ins2 high/Ins1 low Taf4 $^{-1-}$ (clusters 2, 7, 8 and 11). The cell populations segregated in a UMAP representation (Fig. 4D) where $\mathrm{Taf4}^{+/+}$and $\mathrm{Taf4}^{-/-}$beta cells were further distinguished by strongly reduced Ucn3 and Slc2a2 expression (Supplementary Fig. $6 \mathrm{~A})$. High expression of stress markers Ddit3 and Herpud1 characterized $\mathrm{Taf}^{+/+}$beta cells in cluster 5 and $\mathrm{Taf}^{-1-}$ clusters 2 and 8 (Supplementary Fig. 6A). The aggregate also revealed 3 distinct alpha cell populations, cluster 3 from Taf $4^{+/+}$and clusters 4 and 10 from $\mathrm{Taf4}^{-1-}$ with a strong stress response in cluster 4 (Supplementary Fig. 5). Delta cells from the two conditions were more homogenous (cluster 3).

We analysed 2295 cells 1 week after Taf4 inactivation. Clusters 2 and 5 were the most differentiated beta cell populations with high Ins2 and Ucn3 and lowest levels of Gcg and Sst (Fig. 5A). Cluster 2 however was marked by ER stress (Supplementary Fig. 6D). Cluster 0 showed higher Gcg and Sst, although lower than in differentiated alpha and delta cell populations, clusters 3 and 7, respectively, that segregated from the beta cell populations in the UMAP and tSNE representations (Fig. 5B, C and Supplementary $6 \mathrm{~B})$. The small cluster 6 also showed characteristics of a mixed identity population expressing Ins $1 / 2$ and intermediate levels of Gcg. Taf4 inactivation therefore led to several populations with mixed identity expressing Ins2, but also Gcg or Sst and sometimes all three.

Cluster 1 were intermediate cells with lower Ins2, Ucn3 and higher Gcg than the more differentiated clusters 2 and 5. Cluster 4 expressed intermediate levels of Ins2, Gcg and Sst and segregated between the beta, alpha and delta cell populations on the UMAP. Cluster 4 cells lost expression of beta cell-markers $P d x 1$, Mafa and Nkx6.1 and appeared to be trans-differentiating intermediates between beta and alpha cell-like identities (Fig. 5C and Supplementary 6B). Ontology analyses (Supplementary Fig. $6 \mathrm{C}$ and Dataset 2) showed cluster 5 was marked by differentiated beta cell genes, cluster 2 showed translational activity, ER stress associated with high Ddit3 and Herpud1 and high oxidative phosphorylation (Supplementary Fig. 6D). In contrast, signatures for transcription regulation, chromatin modification and RNA metabolism were hallmarks of clusters 1 and 4 consistent with the idea that these cells were undergoing transcriptional reprogramming.

We used SCENIC [42] to identify transcription regulatory networks active in the different cell populations. The SCENICbased tSNE (Fig. 6A) that groups cells based on their regulon activities differed from the expression based tSNE (Fig. 5B), with the beta-cell clusters 2 and 5 grouped together, clusters 1 and 4 grouped closely, while cluster 0 grouped close to alpha cells (Fig. 6A). Consistent with the idea that cluster 5 were differentiated beta cells, they showed high activity of the Mafa, Nkx6-1 and Neurod 1 regulons (Fig. $6 \mathrm{~B}, \mathrm{C}$ ) that were active in cell subpopulations of clusters 0 and 1, but absent from alpha and delta cells. Cluster 2 was marked by activity of Ddit3 and Atf5, that promotes beta-cell survival under stress [43], consistent with their elevated stress response (Fig. 6C, D). In contrast, Mafb activity was seen in alpha cells and in clusters 0,1 and 4 confirming they represented abnormal populations with mixed identities, some showing both Mafa and Mafb activities (Fig. 6B, C).

Strikingly, clusters 0,1 and 4 showed activities of the Arnt2, Bhlhe41, Myc and Nrf1 regulons in line with enhanced binding predicted from ATAC-seq footprinting (Fig. $6 \mathrm{C}$ and E). Clusters 1 and 4 were specifically marked by activity of the small Maf inhibitor Mafg, Tcf4, Tcf12 and the Bptf subunit of the NuRF complex coherent with their chromatin remodelling ontology signatures (Fig. 6C and E). The Foxp1 and Maff regulons showed highest activity in cluster 4 and in differentiated alpha and/or delta cells (Fig. 6C and F). Mafb, Myc, Arnt2, Mafg, Tcf4, Tcf12, Bptf and Foxp1 regulons showed highest combinatorial activity in cluster 4. Moreover, specific activity of Smarca1, the catalytic NuRF complex subunit, in cluster 4 together with Bptf activity suggested a critical role of the NuRF complex in trans-differentiation (Fig. 6C). These results were consistent with a major transcriptional reprogramming and chromatin remodelling associated with trans-differentiation that did not appear to involve transition via a precursor state as low $\mathrm{Ngn} 3$ expression was seen in the delta cell population, but not in clusters 1 and 4 (Fig. 5A). As a result, by 5 weeks two alpha cell populations were observed potentially corresponding to the normal and trans-differentiated populations.

At 5 weeks, no populations with mixed or obviously transdifferentiating characteristics were observed suggesting that trans-differentiation took place immediately after Taf4 loss. SCENIC analyses on 2500 randomly selected cells from the $\mathrm{Taf}^{+/+} / \mathrm{W} 5$ aggregate (Supplementary Fig. 7A) showed that $\mathrm{Taf4}^{+/+}$beta cells were marked by Mafa and the glucosesensing transcription factor Mlxipl, highest in populations 0 and 6 (Supplementary Fig. 7B). Mafa activity was also strong in the $\mathrm{Taf}^{-1-}$ beta cell populations with cluster 11 displaying high 

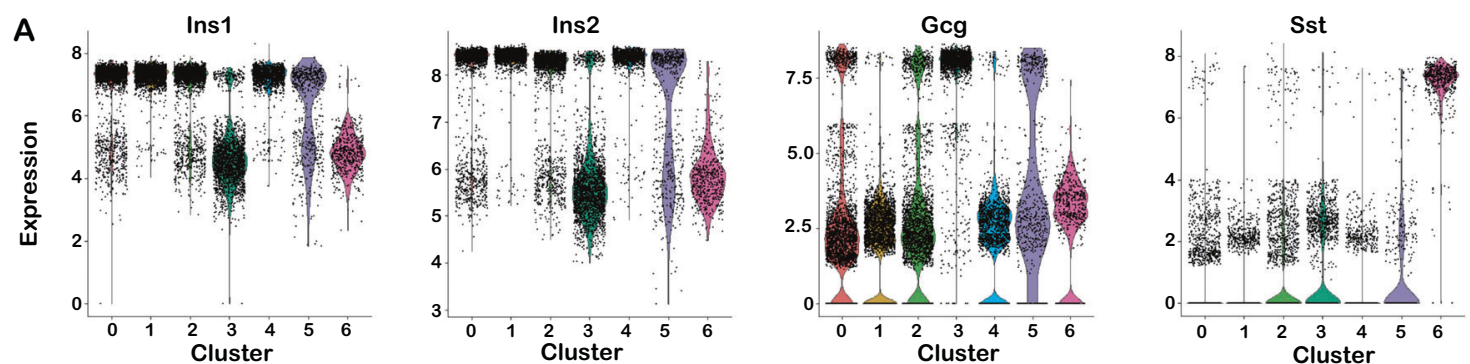

B
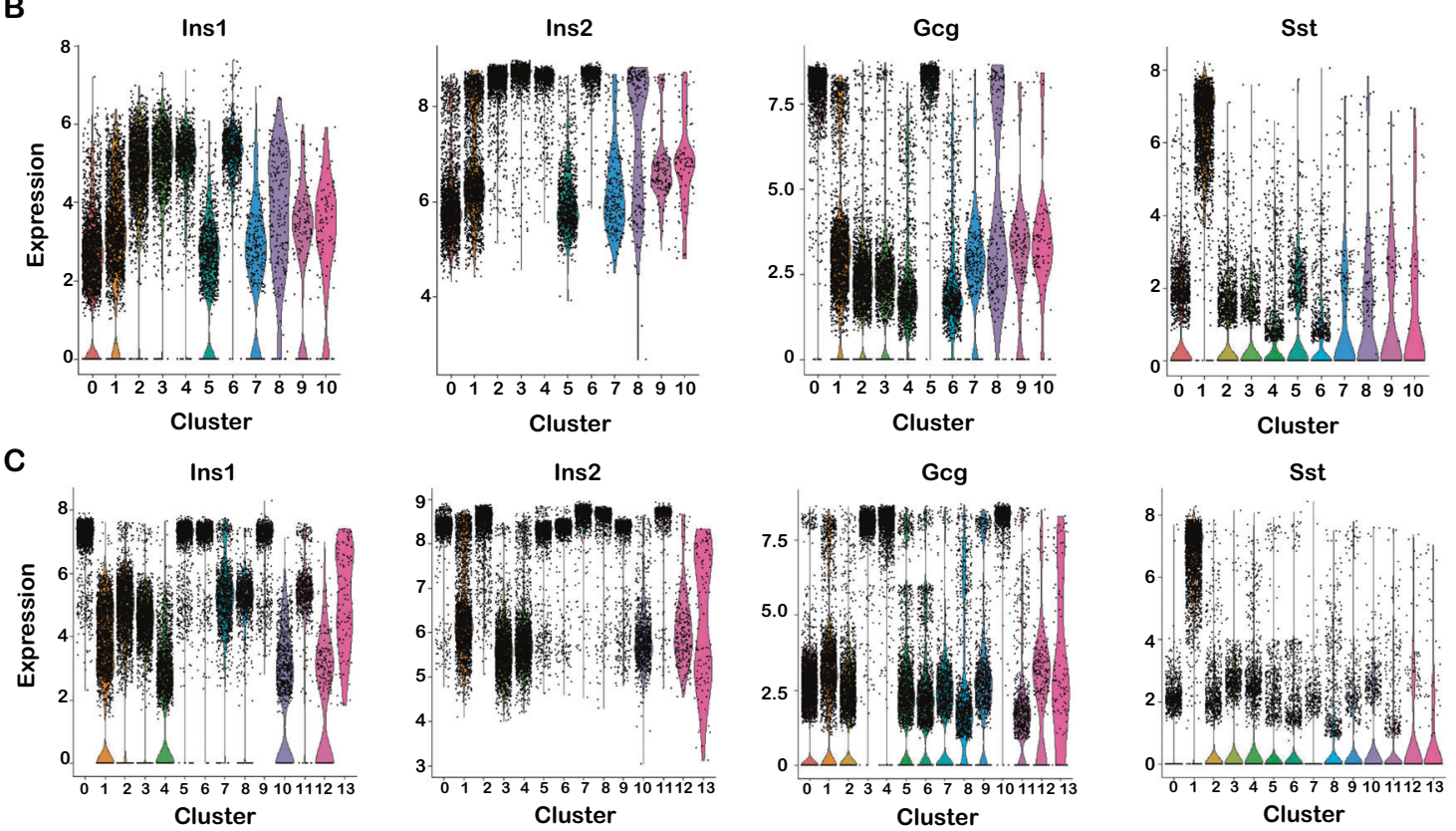

D
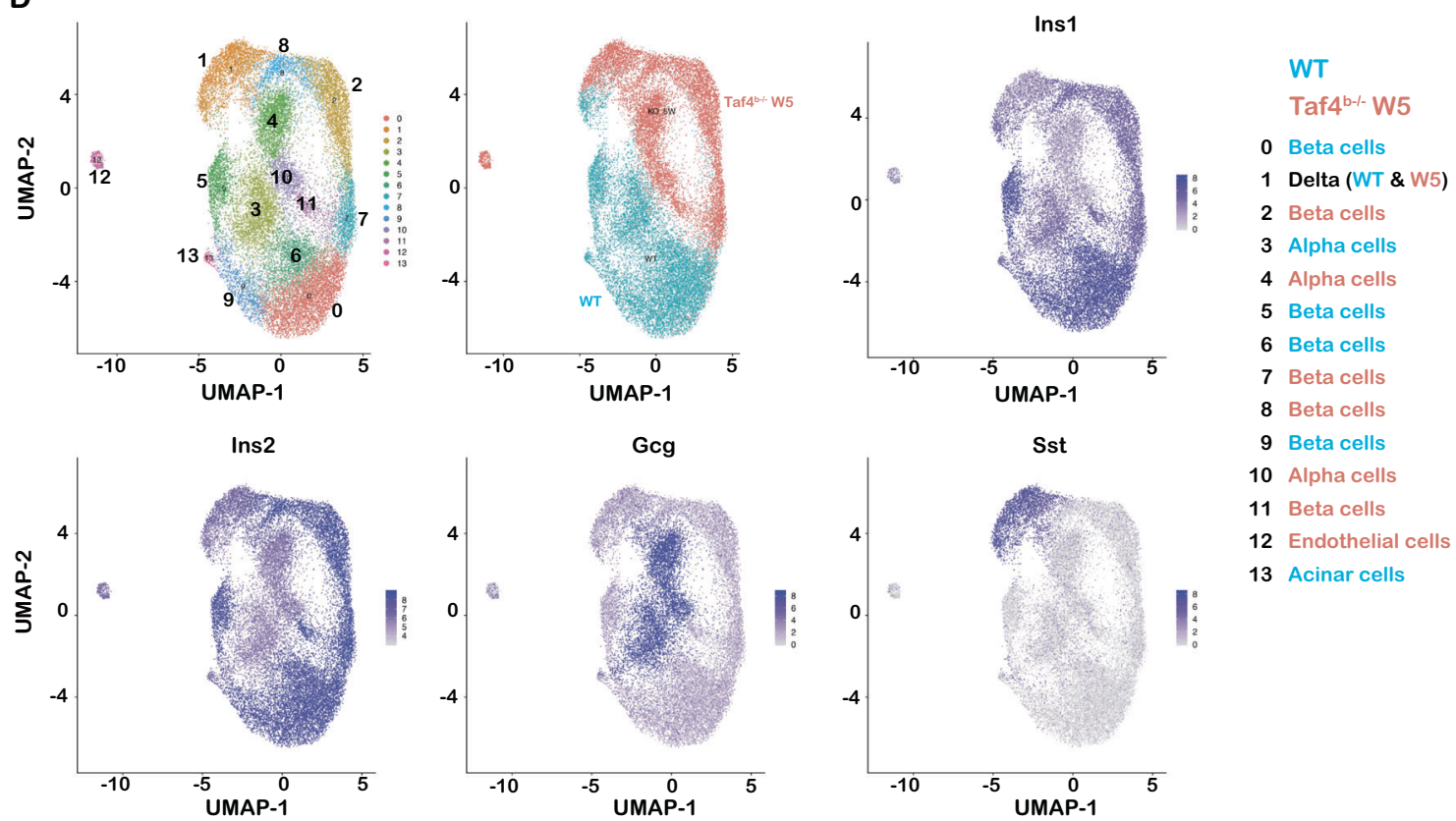

9 Beta cells 10 Alpha cells 11 Beta cells 12 Endothelial cells 13 Acinar cells

Fig. 4 Sc-RNA-seq of WT and week 5 mutant islets. A-C Violin plots of expression of the indicated genes in each cluster from WT islets (A), 5-week mutant islets (B) and the aggregate (C). D UMAP representations of the aggregate data, illustrating origin of cells from WT and mutant animals and the expression of the genes indicated in each panel. 

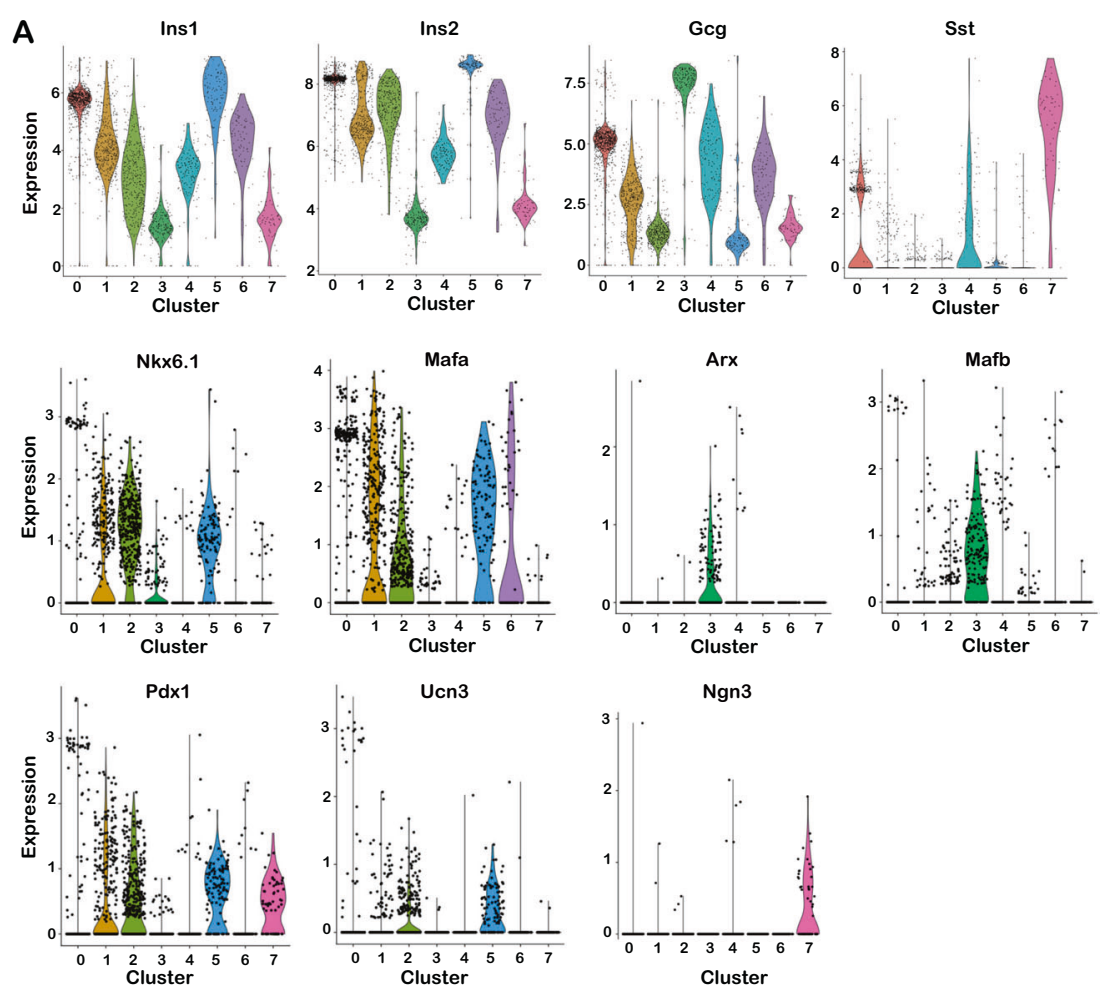

B

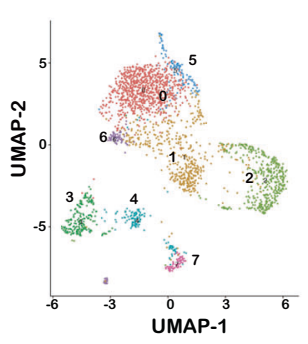

0 Mixed identity

1 Intermediate cells

2 Stressed BCs

3 Differentiated $\alpha$-cells

4 Trans-differentiating cells

5 Differentiated BCs

6 Mixed identity

7 Differentiated $\delta$-cells

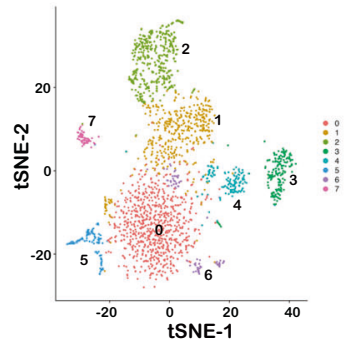

C
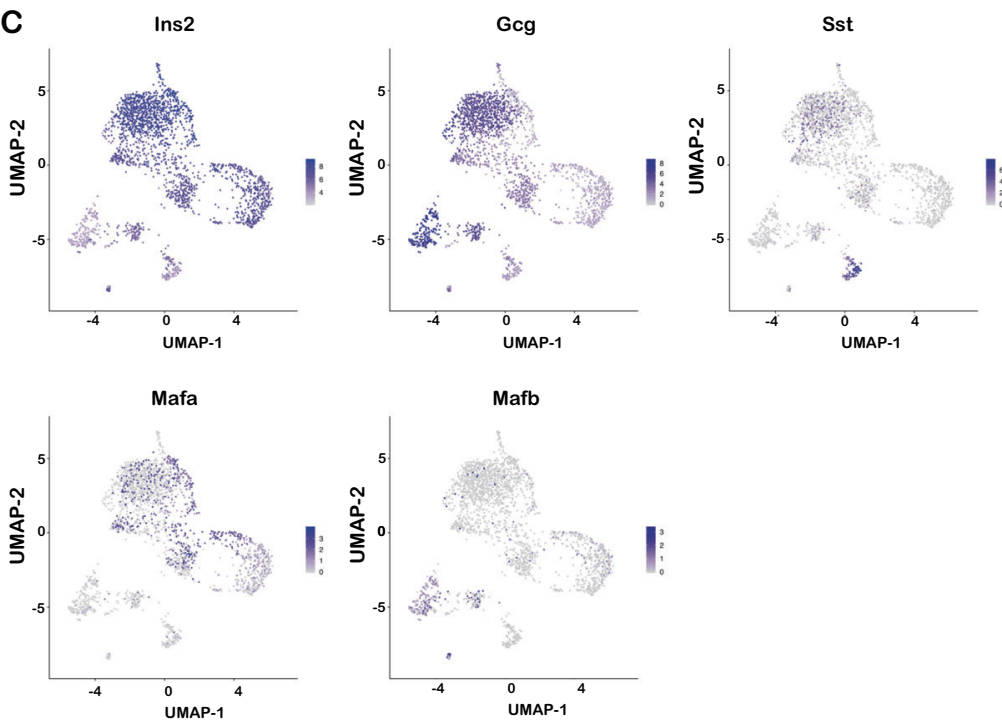

Fig. 5 Sc-RNA-seq of week 1 mutant islets. A Violin plots of expression of the indicated genes in each cluster. B UMAP (left) and tSNE (right) representations of the cell populations. C UMAPs illustrating the expression of the genes indicated in each panel.

activity of both Mafa and Mlxipl. Mafb was active in the alpha cell populations, but contrary to week 1 no overlap of Mafa and Mafb activities was seen. Several $\mathrm{Taf}^{+/+}$beta cell populations characterized by stress response as described above did however show activity of the Mafg, Yy1, Atf5, Atf3, and Bhlhe41 regulons together with those of Jun and Fosb (AP1). Similarly, the stressed Taf4 $^{-1-}$ alpha cells also showed elevated AP1 and Atf3 activity. $\mathrm{Taf4}^{-/-}$beta cells also showed elevated activity of chromatin 
A

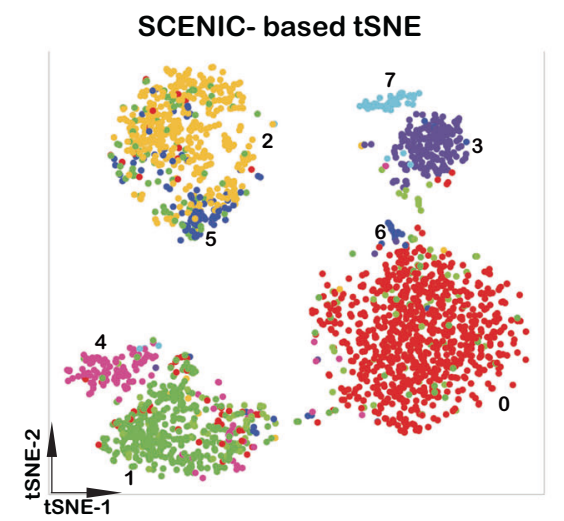

0 Mixed identity

1 Intermediate cells

2 Stressed BCs

3 Differentiated $\alpha$-cells

4 Trans-differentiating cells

5 Differentiated BCs

6 Mixed identity

7 Differentiated $\delta$-cells
C

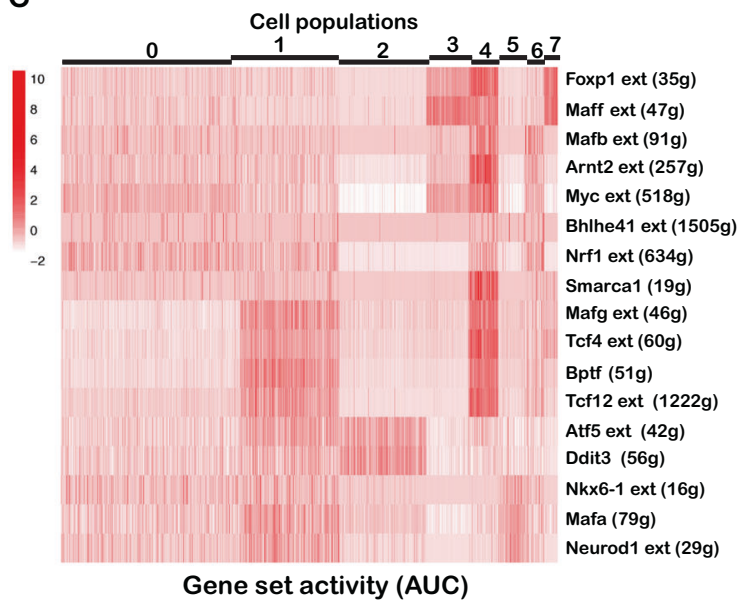

G

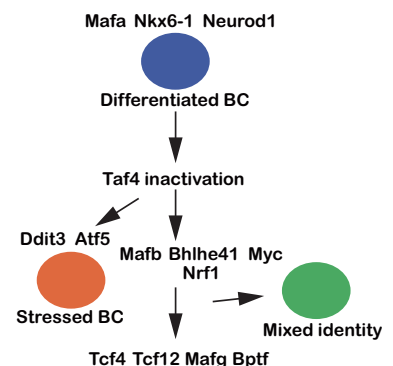

Tcf4 Tcf12 Mafg Bptf

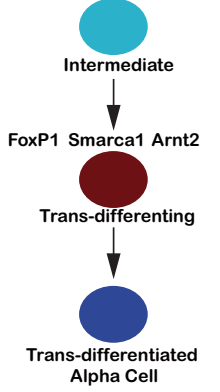

B

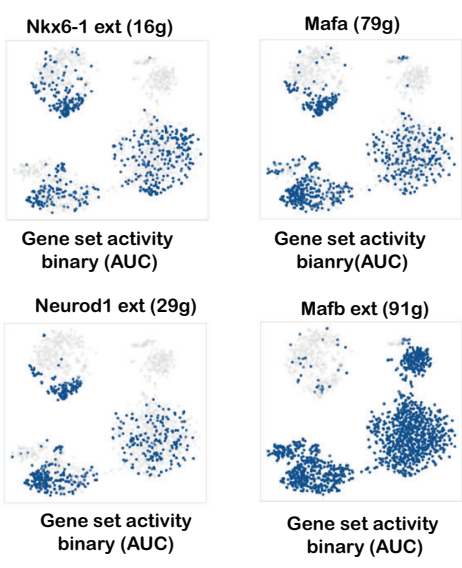

D

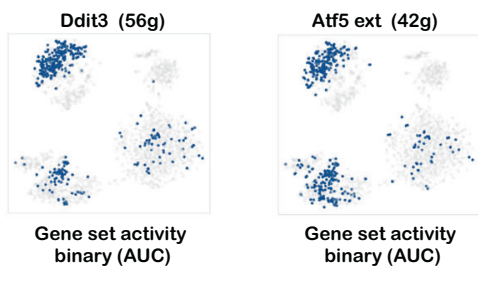

E Arnt2 ext (257g)

Bhlhe41 ext (1505g)
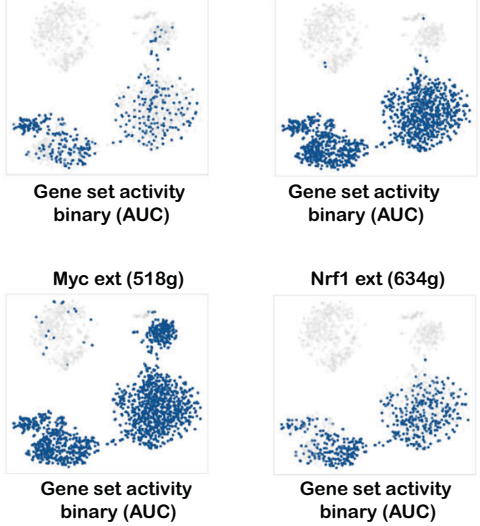

F
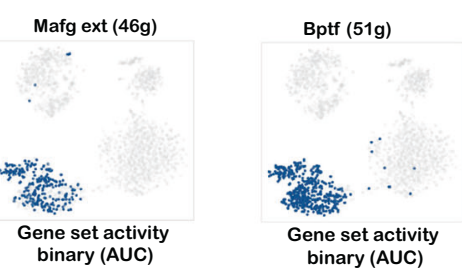

Foxp1 ext (35g)

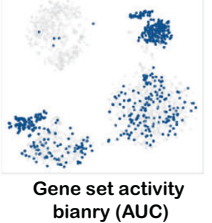

Fig. 6 Transcription factors regulating cell state in week 1 mutant islets. A SCENIC-based tSNE representation colouring cells based on the binary activities of the transcription factor regulons. B, D-E Binary activities of the transcription factor regulons in the different cell populations. C Heatmap of regulon activities in the different cell populations were quantified using AUCell. G A flow-chart of the progression of cell state from differentiated beta cells to trans-differentiated alpha cells. The SCENIC regulons marking the transitions of each state are indicated. 
remodelling factor Chd2. In contrast, activity of all of these regulons was much lower or absent in $\mathrm{Taf}^{+/+}$beta cells.

Trans-differentiation of a sub-population of beta cells into Gcgexpressing apha-like cells was supported by Ins and Gcg coimmunostaining (Supplementary Fig. 8A). In Taf4 ${ }^{+/+}$, Gcg staining was limited to alpha cells surrounding the islet. By 3 weeks after Taf4 inactivation, Gcg-expressing cells were observed both around and amongst the Ins-expressing beta cells, a phenomenon seen later stages and analogous to loss of Pdx1 that promoted beta cell trans-differentiation into Gcg-expressing cells [44]. Such cells were not co-stained with Ins, but labelled uniquely by Gcg.

To confirm beta cell trans-differentiation, we crossed the Ins1::

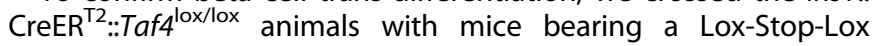
cassette driving a GFP reporter in the Rosa26 locus. Tam administration deleted the Lox-Stop-Lox cassette and activated GFP expression in the beta-cell compartment (Fig. S8B). At 12 weeks after Tam injection, staining with Gcg identified bonefide alpha cells at the periphery of the islets that were negative for GFP, whereas within the islets, most Gcg-expressing cells were GFP positive indicating they trans-differentiated from beta cells.

\section{DISCUSSION}

\section{Taf4 is essential for normal beta-cell function}

Taf4 inactivation in adult murine beta cells led to increased glycaemia due to defective insulin signalling and secretion, a consequence of an immediate and major impact on gene expression. Immunostaining showed a rapid and efficient loss of Taf4 in beta cells by 1 week after Tam injection. At 34 weeks, Taf4expressing beta cells were again detected, but their proportion did not increase by 55 weeks. While it is possible that Taf4expressing beta cells detected at later times arose from rare nonrecombined cells, no Taf4 expressing beta cells were observed upon staining of multiple islets at regular intervals from 3-24 weeks, whereas they were readily observed at 34 and 55 weeks. Furthermore, the number of Taf4-expressing beta cells did not increase between 34 and 55 weeks arguing against proliferation of non-recombined beta cells. Thus, while we cannot definitively exclude the idea that Taf4-expressing cells arose from non-recombined beta cells, an alternative possibility is that they arose from trans-differentiation of alpha cells or other islet populations into beta cells as has been previously described, for example under conditions of reduced beta cell-mass $[2,5,6,12,45]$. Notwithstanding the mechanisms involved, despite chronically high glycaemia, the beta-cell population was only partially and slowly replaced by newly generated Taf4expressing beta cells. Moreover, the Taf4 expressing beta cells seen at later times cannot account for the partially restored glucose and insulin levels seen at 10 weeks, but they may account from the longer-term viability of the animals

\section{A model for beta-cell trans-differentiation}

While there have been several scRNA-seq data sets generated from human adult islet cells [46], studies on adult murine islets have been more limited $[46,47]$. We distinguished several beta cell populations in $\mathrm{Taf}^{+/+}$and $\mathrm{Taf4}^{-/-}$animals with distinct gene expression signatures. Cells with high insulin expression were distinguished from populations with low insulin, but high expression of insulin signalling genes and from a population with high expression of ER stress genes. This is consistent with previous data $[46,47]$ and the idea that high insulin levels induce ER stress prompting cells to transit into a high ER stress/low insulin recovery state. Taf4 inactivation led to a stronger ER stress in a subset of both beta and alpha cells. Wild-type delta cells also displayed high ER stress that was increased upon Taf4 inactivation. This increased cell non-autonomous ER stress after Taf4 inactivation suggested defective communication between the $\mathrm{Taf4}^{-/-}$beta cells and their alpha and delta cell neighbours.
Bulk ATAC-seq and RNA-seq showed that Taf4 inactivation had a potent impact on chromatin accessibility and gene expression with diminished binding of beta cell identify factors. In contrast, increased binding of several transcription factors was predicted from ATAC-seq and several of the corresponding regulons were activated in the abnormal $\mathrm{Taf}^{-1-}$ cell populations. At week 1 , cells with mixed identities displayed regulon activity of beta-cell factors and the alpha cell determinant Mafb, but did not express $A r x$ and therefore displayed an incomplete switch in identity in line with the intermediate levels of Gcg. Previous studies on normal mouse or human pancreas by immune-staining or scRNAseq detected only rare cells simultaneously expressing two of the islet hormones [9, 10, 47-50]. Such cells have however been detected in pathological situations like type 1 and type 2 diabetes and in mice following loss of Arx and Dnmt1 [9]. The mixed cell identity was therefore a consequence of Taf4 inactivation and activation of novel regulons.

Our data pointed to a process of stress-induced beta-cell transdifferentiation. Cluster 4 cells displayed strongly decreased expression and activity of beta-cell factors, but showed Mafb activity, increased Arx and higher Gcg and Sst expression. Furthermore, they were marked by Foxp1 consistent with the essential role of Foxp factors in alpha cells [51] and by activity of Maff, Mafg and the NuRF complex. Inhibition of (s)Maf proteins in beta cells led to increased Mafa activity and beta-cell function correlating with the increased Mafg/Maff activity and loss of betacell identity in the trans-differentiating cells found here $[52,53]$.

We propose a model for beta-cell trans-differentiation involving a progressive loss of beta-cell identity associated with gain of activity for Myc, Mafg, Arnt2, Bhlhe41, Tcf4, Tcf12, Nrf1 and Mafb (Fig. 6G). A population of cells further undergoes chromatin remodelling and transcriptional reprogramming through the combinatorial action of these factors and subsequent acquisition of Foxp1, Maff and Smarca1 activity that promotes transdifferentiation into Gcg-expressing alpha-like cells. Transdifferentiation was further attested by the presence of Gcgexpressing cells intermixed amongst beta cells, and by lineage tracing that confirmed that most Gcg-expressing cells within the islets were indeed derived from beta cells.

Mechanisms of trans-differentiation of alpha to beta-like cells have been documented $[4,8,9,46]$ and examples of beta to alpha-like cell trans-differentiation often involve genetically induced loss of beta cell determinants [11, 14, 44]. In this study, beta cell trans-differentiation also involved loss of beta celldeterminants perhaps triggered by the transient stress and inflammatory response seen 1 week after Taf4 inactivation. This inflammatory/stress environment may be responsible for activation of Myc and previously implicated in beta cell dedifferentiation [54-56].

In previous studies of trans-differentiation, the beta-cell populations actively undergoing trans-differentiation and the associated transcriptional regulatory programs involved are poorly characterized. Using an un-supervised bioinformatics approach, we defined how novel combinations of known critical beta cell and alpha cell determinants act in combination with additional transcription and chromatin remodelling factors to promote betacell trans-differentiation. While different cues may underlie initiation of beta-cell trans-differentiation in pathological situations or following Taf4 inactivation, further studies will determine whether they share common aspects of the transcriptional reprogramming described here.

\section{DATA AVAILABILITY}

Source data for this paper are available from the authors upon reasonable request. All sequencing data reported here have been submitted to the GEO database under accession number GSE151366. 


\section{REFERENCES}

1. Puri $S$, Folias $A E$, Hebrok M. Plasticity and dedifferentiation within the pancreas: development, homeostasis, and disease. Cell Stem Cell. 2015;16:18-31.

2. Thorel F, Nepote V, Avril I, Kohno K, Desgraz R, Chera S, et al. Conversion of adult pancreatic alpha-cells to beta-cells after extreme beta-cell loss. Nature. 2010;464:1149-54.

3. van der Meulen T, Mawla AM, DiGruccio MR, Adams MW, Nies V, Dolleman S, et al. Virgin beta cells persist throughout life at a neogenic niche within pancreatic islets. Cell Metab. 2017;25:911-26 e916.

4. Chera S, Baronnier D, Ghila L, Cigliola V, Jensen JN, Gu G, et al. Diabetes recovery by age-dependent conversion of pancreatic delta-cells into insulin producers. Nature. 2014;514:503-7.

5. Moin ASM, Butler AE. Alterations in beta cell identity in type 1 and type 2 diabetes. Curr Diab Rep. 2019;19:83.

6. Zhou Q, Melton DA. Pancreas regeneration. Nature. 2018;557:351-8.

7. Ackermann AM, Wang Z, Schug J, Naji A, Kaestner KH. Integration of ATAC-seq and RNA-seq identifies human alpha cell and beta cell signature genes. Mol Metab. 2016;5:233-44

8. Furuyama K, Chera S, van Gurp L, Oropeza D, Ghila L, Damond N, et al. Diabetes relief in mice by glucose-sensing insulin-secreting human alpha-cells. Nature. 2019;567:43-48.

9. Chakravarthy H, Gu X, Enge M, Dai X, Wang Y, Damond N, et al. Converting adult pancreatic islet alpha cells into beta cells by targeting both Dnmt1 and Arx. Cell Metab. 2017;25:622-34.

10. Tritschler S, Theis FJ, Lickert $\mathrm{H}$, Bottcher A. Systematic single-cell analysis provides new insights into heterogeneity and plasticity of the pancreas. Mol Metab. 2017;6:974-90.

11. Talchai C, Xuan S, Lin HV, Sussel L, Accili D. Pancreatic beta cell dedifferentiation as a mechanism of diabetic beta cell failure. Cell. 2012;150:1223-34.

12. Hunter CS, Stein RW. Evidence for loss in identity, de-differentiation, and transdifferentiation of islet beta-cells in type 2 diabetes. Front Genet. 2017;8:35.

13. Benninger RKP, Dorrell C, Hodson DJ, Rutter GA. The impact of pancreatic beta cell heterogeneity on type 1 diabetes pathogenesis. Curr Diab Rep. 2018;18:112.

14. Papizan JB, Singer RA, Tschen SI, Dhawan S, Friel JM, Hipkens SB, et al. Nkx2.2 repressor complex regulates islet beta-cell specification and prevents beta-toalpha-cell reprogramming. Genes Dev. 2011;25:2291-305.

15. Dhawan S, Georgia S, Tschen SI, Fan G, Bhushan A. Pancreatic beta cell identity is maintained by DNA methylation-mediated repression of Arx. Dev Cell. 2011;20:419-29.

16. Levine $M$, Tjian R. Transcription regulation and animal diversity. Nature 2003;424:147-51.

17. Taatjes DJ, Marr MT, Tjian R. Regulatory diversity among metazoan co-activato complexes. Nat Rev Mol Cell Biol. 2004;5:403-10.

18. Bell B, Tora L. Regulation of gene expression by multiple forms of TFIID and other novel TAFII-containing complexes. ExpCell Res. 1999;246:11-19.

19. Malik S, Roeder RG. The metazoan mediator co-activator complex as an integrative hub for transcriptional regulation. Nat Rev Genet. 2010;11:761-72.

20. Muller F, Tora L. The multicoloured world of promoter recognition complexes. Embo J. 2004;23:2-8.

21. Cler E, Papai G, Schultz P, Davidson I. Recent advances in understanding the structure and function of general transcription factor TFIID. Cell Mol Life Sci. 2009:66:2123-34.

22. Bhuiyan T, Timmers HTM. Promoter recognition: putting TFIID on the spot. Trends Cell Biol. 2019;29:752-63.

23. Patel AB, Greber BJ, Nogales E. Recent insights into the structure of TFIID, its assembly, and its binding to core promoter. Curr Opin Struct Biol. 2019;61:17-24.

24. Patel AB, Louder RK, Greber BJ, Grunberg S, Luo J, Fang J, et al. Structure of human TFIID and mechanism of TBP loading onto promoter DNA. Science. 2018;362:eaau8872. https://doi.org/10.1126/science.aau8872.

25. Wright KJ, Marr MT 2nd, Tjian R. TAF4 nucleates a core subcomplex of TFIID and mediates activated transcription from a TATA-less promoter. Proc Natl Acad Sci USA. 2006;103:12347-52.

26. Alpern D, Langer D, Ballester B, Le Gras S, Romier C, Mengus G, et al. TAF4, a subunit of transcription factor \| $D$, directs promoter occupancy of nuclear receptor HNF4A during post-natal hepatocyte differentiation. Elife. 2014;3: e03613.

27. Mengus G, Fadloun A, Kobi D, Thibault C, Perletti L, Michel I, et al. TAF4 inactivation in embryonic fibroblasts activates TGFbeta signalling and autocrine growth. Embo J. 2005;24:2753-67.

28. Langer D, Martianov I, Alpern D, Rhinn M, Keime C, Dolle P, et al. Essential role of the TFIID subunit TAF4 in murine embryogenesis and embryonic stem cell differentiation. Nat Commun. 2016;7:11063.

29. Fadloun A, Kobi D, Pointud JC, Indra AK, Teletin M, Bole-Feysot $C$, et al. The TFIID subunit TAF4 regulates keratinocyte proliferation and has cell-autonomous and non-cell-autonomous tumour suppressor activity in mouse epidermis. Development. 2007:134:2947-58.

30. Fadloun A, Kobi D, Delacroix L, Dembele D, Michel I, Lardenois A, et al. Retinoic acid induces TGFbeta-dependent autocrine fibroblast growth. Oncogene. 2008;27:477-89.

31. Martianov I, Cler E, Duluc I, Vicaire S, Philipps M, Freund JN, et al. TAF4 inactivation reveals the 3 dimensional growth promoting activities of collagen $6 \mathrm{~A} 3$. PLoS ONE. 2014;9:e87365.

32. Piccand J, Strasser P, Hodson DJ, Meunier A, Ye T, Keime C, et al. Rfx6 maintains the functional identity of adult pancreatic beta cells. Cell Rep. 2014;9:2219-32.

33. Anders S, Huber W. Differential expression analysis for sequence count data Genome Biol. 2010;11:R106.

34. Love Ml, Huber W, Anders S. Moderated estimation of fold change and dispersion for RNA-seq data with DESeq2. Genome Biol. 2014;15:550.

35. Langmead B, Trapnell C, Pop M, Salzberg SL. Ultrafast and memory-efficient alignment of short DNA sequences to the human genome. Genome Biol. 2009;10:R25.

36. Zhang Y, Liu T, Meyer CA, Eeckhoute J, Johnson DS, Bernstein BE, et al. Modelbased analysis of ChIP-Seq (MACS). Genome Biol. 2008;9:R137.

37. Quinlan AR, Hall IM. BEDTools: a flexible suite of utilities for comparing genomic features. Bioinformatics. 2010;26:841-2.

38. Ye T, Krebs AR, Choukrallah MA, Keime C, Plewniak F, Davidson I, et al. seqMINER an integrated ChIP-seq data interpretation platform. Nucleic Acids Res. 2011;39:e35

39. Bentsen M, Goymann P, Schultheis $H$, Klee K, Petrova A, Wiegandt R, et al. ATAC seq footprinting unravels kinetics of transcription factor binding during zygotic genome activation. Nat Commun. 2020;11:4267. https://doi.org/10.1038/s41467020-18035-1.

40. McGinnis CS, Murrow LM, Gartner ZJ. DoubletFinder: doublet detection in single-cell RNA sequencing using artificial nearest neighbors. Cell Syst. 2019;8:329-37.e324.

41. Stuart T, Butler A, Hoffman P, Hafemeister C, Papalexi E, Mauck WM 3rd, et al Comprehensive Integration of Single-. Cell Data Cell. 2019;177:1888-902 e1821.

42. Aibar S, Gonzalez-Blas CB, Moerman T, Huynh-Thu VA, Imrichova H, Hulselmans $\mathrm{G}$, et al. SCENIC: single-cell regulatory network inference and clustering. Nat Methods. 2017;14:1083-6.

43. Juliana CA, Yang J, Rozo AV, Good A, Groff DN, Wang SZ, et al. ATF5 regulates beta-cell survival during stress. Proc Natl Acad Sci USA. 2017;114:1341-6.

44. Gao T, McKenna B, Li C, Reichert M, Nguyen J, Singh T, et al. Pdx1 maintains beta cell identity and function by repressing an alpha cell program. Cell Metab. 2014;19:259-71.

45. Cinti F, Bouchi R, Kim-Muller JY, Ohmura Y, Sandoval PR, Masini M, et al. Evidence of beta-cell dedifferentiation in human type 2 diabetes. J Clin Endocrinol Metab. 2016;101:1044-54.

46. $\mathrm{Yu} X X, \mathrm{Xu} C R$. Understanding generation and regeneration of pancreatic beta cells from a single-cell perspective. Development. 2020;147:dev179051. https:// doi.org/10.1242/dev.179051.

47. Baron M, Veres A, Wolock SL, Faust AL, Gaujoux R, Vetere A, et al. A single-cell transcriptomic map of the human and mouse pancreas reveals inter- and intracell population structure. Cell Syst. 2016;3:346-60.e344.

48. Sharma RB, O'Donnell AC, Stamateris RE, Ha B, McCloskey KM, Reynolds PR, et al. Insulin demand regulates beta cell number via the unfolded protein response. $J$ Clin Invest. 2015;125:3831-46.

49. Muraro MJ, Dharmadhikari G, Grun D, Groen N, Dielen T, Jansen E, et al. A singlecell transcriptome atlas of the human pancreas. Cell Syst. 2016;3:385-94.e383.

50. Xin Y, Kim J, Okamoto H, Ni M, Wei Y, Adler C, et al. RNA sequencing of single human islet cells reveals type 2 diabetes genes. Cell Metab. 2016;24:608-15.

51. Spaeth JM, Hunter CS, Bonatakis L, Guo M, French CA, Slack I, et al. The FOXP1, FOXP2 and FOXP4 transcription factors are required for islet alpha cell proliferation and function in mice. Diabetologia. 2015;58:1836-44.

52. Nomoto $H$, Kondo T, Miyoshi $H$, Nakamura A, Hida $Y$, Yamashita $K$, et al. Inhibition of small maf function in pancreatic beta-cells improves glucose tolerance through the enhancement of insulin gene transcription and insulin secretion Endocrinology. 2015;156:3570-80.

53. Katsuoka F, Yamamoto M. Small Maf proteins (MafF, MafG, MafK): history, structure and function. Gene. 2016;586:197-205.

54. Laybutt DR, Weir GC, Kaneto H, Lebet J, Palmiter RD, Sharma A, et al. Overexpression of c-Myc in beta-cells of transgenic mice causes proliferation and apoptosis, downregulation of insulin gene expression, and diabetes. Diabetes. 2002;51:1793-804.

55. Bensellam M, Jonas JC, Laybutt DR. Mechanisms of beta-cell dedifferentiation in diabetes: recent findings and future research directions. J Endocrinol. 2018;236 R109-43.

56. Pascal SM, Guiot $Y$, Pelengaris $S$, Khan M, Jonas JC. Effects of c-MYC activation on glucose stimulus-secretion coupling events in mouse pancreatic islets. Am J Physiol Endocrinol Metab. 2008;295:E92-102. 


\section{ACKNOWLEDGEMENTS}

We thank, I Michel for excellent technical assistance, all the staff of the IGBMC common facilities in particular the IGBMC animal, high throughput sequencing (GenomEast) and electron microscopy facilities, the Mouse Clinical Institute for help with the measurement of insulin and glucose levels.

\section{AUTHOR CONTRIBUTIONS}

TK performed the physiological, histological, part of the immunostaining and gene expression analyses, GD performed bioinformatics analyses, IM performed immunostaining, GM managed the breeding, housing and genotyping of the mice. TK, GD and ID conceived the experiments analysed the data and wrote the paper.

\section{FUNDING}

This work was supported by institutional grants from the Centre National de la Recherche Scientifique, the Institut National de Santé et de la Recherche Médicale, the Université de Strasbourg, the Ligue Nationale contre le Cancer, Agence Nationale de la Recherche (ANR)-15-CE14-003 project Dysmetaf, the ANR-10-LABX-0030-INRT French state fund under the framwork programme Investissements d'Avenir ANR-10IDEX-0002-02. The IGBMC high throughput sequencing facility is a member of the "France Génomique" consortium (ANR10-INBS-09-08). ID is an 'équipe labellisée' of the Ligue Nationale contre le Cancer. TK was supported by fellowships from the ANR and the FRM.

\section{ETHICS STATEMENT}

This study did not involve any human patients. All animal experiments were performed in accordance with European and national guidelines and policies (2010/ 63/UE directive and French decree 2013-118) and with approval of the National Ethics Committee.

\section{COMPETING INTERESTS}

The authors declare no competing interests.

\section{ADDITIONAL INFORMATION}

Supplementary information The online version contains supplementary material available at https://doi.org/10.1038/s41419-021-04067-y.

Correspondence and requests for materials should be addressed to I.D.

Reprints and permission information is available at http://www.nature.com/ reprints

Publisher's note Springer Nature remains neutral with regard to jurisdictional claims in published maps and institutional affiliations.

\section{(c) (i)}

Open Access This article is licensed under a Creative Commons Attribution 4.0 International License, which permits use, sharing, adaptation, distribution and reproduction in any medium or format, as long as you give appropriate credit to the original author(s) and the source, provide a link to the Creative Commons license, and indicate if changes were made. The images or other third party material in this article are included in the article's Creative Commons license, unless indicated otherwise in a credit line to the material. If material is not included in the article's Creative Commons license and your intended use is not permitted by statutory regulation or exceeds the permitted use, you will need to obtain permission directly from the copyright holder. To view a copy of this license, visit http://creativecommons. org/licenses/by/4.0/.

(c) The Author(s) 2021 